Monika OŻÓG*

\title{
MAGIC PRACTICES AGAINST HUMAN LIFE AND HEALTH IN LATE ANTIQUITY AS REFLECTED IN CHURCH LEGISLATION**
}

From time immemorial, magic practices and customs have been an integral element of culture. Extensive evidence in the form of a variety of amulets, utensils, and magic formulas has been found in many parts of the world. Magic would also permeate the world of religious beliefs. It was a constitutive part of being a religious person, at times to such an extent that it would have been difficult to tell one from the other depending on a specific period in history. My intention is neither to offer a comprehensive analysis of the entire phenomenon nor to explore its origin and diversity. Incidentally, there is a considerable amount of literature on the subject, some of which I refer to in this article ${ }^{1}$.

The present topic is concerned with magic practices harmful to life and health as defined in the body of relevant church legislation. I am aware of the fact that legal regulations are intended to eliminate errors and threats, and would consequently tend to present a somewhat one-sided picture that cannot reflect all the complexities of life. Nonetheless, they certainly refer to the real dangers and, as a result, broaden our understanding of the period. At the same time, I would like to make it clear that I am only concerned here with magic practices that were undertaken with the intention to bring harm to someone, not with unfortunate incidents such as causing a person's death as a result of giving them a magic potion that was supposed to have healed that person. It would have been something similar to the modern day cases of medical "malpractice", generally not qualified as criminal offences. This type of magic, harmful to human life or health, is usually considered to be black magic, even though it would not always bear the hallmarks of this concept. Other practices, such as inducing a man to abandon his wife in order to take up a relationship

*Dr hab. Monika Ożóg, independent researcher; e-mail: monika.ozog@onet.eu.

** This text was written as part of the research project National Science Centre: „Collecting, preparing and publishing research in the original languages with a Polish translation of the synods, canons and penitentiary texts of the antiquity Church" (the registration number N N101 324834).

${ }^{1}$ See the bibliography in: A. Wypustek, Magia antyczna, Wrocław 2001, 382-390; R. Wiśniewski, Wróżbiarstwo chrześcijańskie w późnym antyku czyli jak poznać przyszłość i nie utracić zbawienia, Warszawa 2013, 2-6. 
with another woman, would be also defined as an act of black magic ${ }^{2}$. Not necessarily to the detriment of life or physical health, it might have been something damaging to someone's mental health.

This kind of distinction, black and white magic, allowing the latter to continue in existence, would be reflected in the constitution issued by Emperor Constantine and his son Crispus, co-consuls in 318 or $321^{3}$, subsequently repeated in the Codex Iustinianus ${ }^{4}$ :

"The science of those men who are equipped with magic arts and who are revealed to have worked against the safety of men or to have turned virtuous minds to lust shall be punished and deservedly avenged by the most severe laws. But remedies sought for human bodies shall not be involved in criminal accusation, nor the assistance that is innocently employed in rural districts in order that rains may not be feared for the ripe grape harvests or that the harvests may not be shattered by the stones of ruinous hail, since by such devices no person's safety or reputation is injured, but by their action they bring it about that divine gifts and the labors of men are not destroyed"5.

"Most severe laws" would be normally used as a euphemistic expression in reference to the death penalty and in the rhetoric of the late antique legislation it doesn't have to mean it ${ }^{6}$. It is significant that the magical practices harmful to physical and public health are put on par here, the latter category relating to the "health" of a family disrupted by the measures employed to divert someone's affection from his or her lawful spouse and instead to somebody

${ }^{2}$ Cf. R. Kieckhefer, La magia nel medioevo, Roma 2003, 101-104.

${ }^{3}$ For preferences of various scholars in the matter of the dating of this constitution, see O. Seeck, Regesten der Kaiser und Päpste für die Jahre 311 bis 476 n. Chr. Vorarbeit zu einer Prosopographie der christlichen Kaiserzeit, Stuttgart 1919, 62 and 166; P. Porena, Le origini della prefettura del pretorio tardoantica, Roma 2003, 348-349.

${ }^{4}$ Cf. CJ IX 18, 4, ed. P. Krueger, Corpus Iuris Civilis, vol. 2, Berolini 1877, 380.

${ }^{5}$ CTh IX 16, 3, ed. J. Delmaire, SCh 531, Paris 2009, 138-140: “Idem A. et Caes. [= Imp. Constantinus] ad Bassum $\mathrm{p}($ raefectum) $\mathrm{u}(\mathrm{rbi})$. Eorum est scientia punienda et severissimis merito legibus vindicanda, qui magicis accincti artibus aut contra hominum moliti salutem aut pudicos ad libidinem deflexisse animos detegentur. Nullis vero criminationibus implicanda sunt remedia humanis quaesita corporibus aut in agrestibus locis, ne maturis vindemiis metuerentur imbres aut ruentis grandinis lapidatione quaterentur, innocenter adhibita suffragia, quibus non cuiusque salus aut existimatio laederetur, sed quorum proficerent actus, ne divina munera et labores hominum sternerentur", transl. C. Pharr, in: The Theodosian Code and Novels and the Sirmondian Constitutions, Princeton University Press 1952, 237. Cf. D.S. Kalleres, Drunken Hags with Amulets and Prostitutes with Erotic Spells: The Re-Feminization of Magic in Late Antique Christian Homilies, in: Daughters of Hecate: Women and Magic in the Ancient World, ed. K.B. Stratton - D.S. Kalleres, Oxford 2014, 229.

${ }^{6} \mathrm{Cf}$. M. Stachura, Wrogowie porzadku rzymskiego. Studium zjawiska agresji językowej w Kodeksie Teodozjusza, Nowelach Postteodozjańskich i Konstytucjach Sirmondiańskich, Kraków 2010, 134. 
else $^{7}$. It must be noted that the practices deemed here as permissible, or even beneficial, would not be supported by Christian authors, who were critical of any manifestation of magic. The supposition that the emperor would impose capital punishment for practising black magic was based upon legal tradition, and magic crafts began to be associated with crimes against the state, notably envisioned as high treason ${ }^{8}$. In Paulus' Sentences such actions undertaken to do harm to a person would be punished with the penalty of crucifixion or throwing the perpetrator to wild animals ${ }^{9}$. As Maciej Jońca argues, the phrase "godless and nocturnal ceremonies" could be linked with the forbidden practices taking place at cemeteries ${ }^{10}$.

Necromancy, magic arts, and the use of such crafts to the detriment of human life are also condemned in Emperor Constantius II's constitution of 357:

"Many persons who dare to disturb the elements by magic arts do not hesitate to jeopardize the lives of innocent persons and dare to torment them by summoning the spirits of the dead, so that everyone may destroy his enemies by evil arts. A deadly curse shall annihilate such persons, since they are foreign to nature"

Apart from the obvious influence of the old laws upon the new legislation in Rome, some scholars argue that Bishop Hosius of Cordoba may have effectively influenced Constantine, which would have also presupposed the influence of the synod of Elvira. As a matter of fact, this synod, which took place around the year 306, was the first voice of the institutional Church addressing the magic practices harmful to life and health. According to one of the canons:

"If someone kills another by means of a maleficium, which cannot be done without idolatry, shall not receive communion even in the extremity of death"12.

\footnotetext{
${ }^{7}$ One may refer in this point to the quotations taken from Arnobius (Adversus gentes I 43, 5)
} and Ammianus Marcellinus (Rerum gestarum lib. XXVIII 1, 14).

${ }^{8} \mathrm{Cf}$. L. Desanti, Sileat omnibus perpetuo divinandi curiositas. Indovini e sanzioni nel diritto romano, Milano 1990, 61-86.

${ }^{9}$ Cf. Pauli Sententiae V 23, 14, ed. S. Riccobono, Fontes Iuris Romani Anteiustiniani, vol. 2, Florentiae 1964, 409: "Qui abortionis aut amatorium poculum dant, etsi id dolo non faciant, tamen quia mali exempli res est, humiliores in metallum, honestiores in insulam amissa parte bonorum relegantur: quod si ex hoc mulier aut homo perierit, summo supplicio adficiuntur".

${ }^{10} \mathrm{Cf}$. M. Jońca, Przestępstwo znieważenia grobu w rzymskim prawie karnym, Lublin 2013, 162.

${ }^{11} \mathrm{CTh}$ IX 16, 5, SCh 531, 144: "Multi magicis artibus ausi elementa turbare vitas insontium labefactare non dubitant et manibus accitis audent ventilare, ut quisque suos conficiat malis artibus inimicos. Hos, quoniam naturae peregrini sunt, feralis pestis absumat", transl. C. Pharr, p. 237-238.

${ }^{12}$ Concilium Eliberitanum (306) can. 6, SCL I, 51: "Si quis vero maleficio interficiat alterum, eo quod sine idololatria perficere scelus non potuit, nec in finem impertiendam esse illi communionem". If not indicated otherwise, all further quotations are translated by author directly from Latin and Greek. Cf. G. Marasco, La condanna della magia nei concili occidental del IV secolo D.C., SEA 78, Roma 2002, 73. In regards to the ambiguity of the term meleficium see P. Lee-Stecum, Dangerous Reputations: Charioteers and Magic in Fourth-Century Rome, „Greece \& Rome” 53 (2006) fasc. 2, 
The legislator assumes that any curse in itself does not have the power to kill or any power at all, but it is in fact an act of summoning "alien gods" or demons that become empowered to take action. For this reason, sanctions for killing a person by magic practices are more severe than for killing with no recourse to magic. None of the synodal canons deals with this question exhaustively; only one canon refers to the killing of a slave woman by her mistress: if she had done that with premeditated intent, she should perform penitential acts for seven years ${ }^{13}$. This canon comes immediately before the one referring to killing by witchcraft, and therefore it could be assumed that the council fathers may have seen a relation between those canons. It would be difficult, however, to prove that such influence of the Elvira synod on Constantine had indeed taken place. I would agree with Gabriel Marasco's view that the civil law tradition, which was consistent in making a clear distinction between black and white magic, was a sufficient source for the emperor's legislation ${ }^{14}$.

Of course, any instance of witchcraft or magic practices is reprehensible in the eyes of the Church, but the intended purpose would change the classification of such an act. It is also relevant to situations which nowadays would be far from being considered magic, yet they would have been perceived as such in ancient times as there was no way to think of them otherwise. Among other things, all actions aiming to bring about a miscarriage would be the case in point ${ }^{15}$. While the synod of Ancyra (314) imposed a five-year-long period of atonement for "ordinary" witchcraft intended to ensure well-being and safety for a person's household ${ }^{16}$, causing an abortion $\delta i \alpha$ $\varphi \theta o p i \omega v$, i.e., through the use of some mixtures/potions usually concocted by witches, would demand a stricter penance, to be done for as long as 10 years "according to determined degrees"17. These are defined in one of the first canons and refer to the

224-234; M.V. Escribano Paño, Heretical texts and maleficium in the „Codex Theodosianus” (CTh. 16.5.34), in: Magical practice in the Latin West. Papers from the international conference held at the University of Zaragoza 30.09-1.10.2005, ed. R.L. Gordon - F.M. Simón, Leiden 2010, 105-138.

${ }^{13}$ Cf. Concilium Eliberitanum (306) can. 5, SCL 1, ed. A. Baron - H. Pietras, ŹMT 37, Kraków 2006, 51: "Si qua femina furore zeli accensa flagris verberaverit ancillam suam, ita ut intra tertium diem animam cum cruciatu effundat, eo quod incertum sit voluntate an casu occiderit; si voluntate, post septem annos, si casu, post quinquennii tempora, acta legitima poenitentia ad communionem placuit admitti; quod si infra tempora constituta fuerit infirmata, accipiat communionem".

${ }^{14} \mathrm{Cf}$. Marasco, La condanna della magia, p. 74-77.

${ }^{15}$ On abortion in Antiquity, see S. Longosz, Ojcowie Kościoła a przerywanie ciaży, cz. 1: Okres przedchrześcijański, VoxP 5 (1985) vol. 8-9, 231-294; idem, Aborcja i porzucanie dzieci w starożytności pogańskiej i chrześcijańskiej. Materiały bibliograficzne, RT 51 (2004) vol. 10, 279-291; idem, Prawo rzymskie wobec aborcji, w: Contra leges et bonos mores. Przestepstwa obyczajowe w starożytnej Grecji i Rzymie, ed. H. Kowalski - M. Kuryłowicz, Lublin 2005, 209-220.

${ }^{16}$ Cf. Concilium Ancyranum (314) can. 24, SCL 1, 68.

${ }^{17}$ Ibidem can. 21, SCL 1, 67. See Kieckhefer, La magia nel medioevo, p. 52. 
individual stages of catechumenate: listening, lying prostrate, taking part in prayers without full communion ${ }^{18}$.

The prohibition against practising magic and preparing magic potions, in the context of causing an abortion, can be already found in the Didache:

"[...] you shall not practice magic, you shall not practice witchcraft, you shall not murder a child by abortion nor kill that which is begotten"19.

Just as the entire Didache, this passage is cited word for word in the Apostolic Constitutions as it must have clearly corresponded with the convictions of the compilers of this collection of laws composed most probably at Antioch in the late $4^{\text {th }}$ century. It is worth noting that neither Didache nor Constitutions set down any penance for this forbidden act. At about the same time, in Asia as well, this issue was framed in precise terms by Basil the Great. His canons, which would be embraced by the legislation of the Orthodox Church, provided for acts of penance to be fulfilled by those who would engage in magic arts/ witchcraft, regardless of its nature. In Basil's words:

"Whoever confessed to having practised magic or made magic potions should spend as much time doing penance as murderers, because he incriminated himself with such a $\sin ^{\prime 20}$.

In theory, the term $\varphi \alpha \rho \mu \alpha \kappa \varepsilon i \alpha$, as used in those sources, would refer to making use of all medications and remedies, not just potions prepared with the intent of bringing harm on a person ${ }^{21}$. Basil does not make it specific if such mixtures would be intended to serve as remedy or poison; in any case, he regards the use of such substances as tantamount to the sin of homicide. It is rather difficult to explain the rigorous character of this precept, still it would be subsequently approved within the Church, at least in the East, and not only in the $4^{\text {th }}$ century, as Basil's canons would be affirmed at the council in Trullo in $691^{22}$. Moreover, in addition to the affirmation of Basil's canons, the council fathers formulated and included their own canon, as if to dispel any possible doubt:

${ }^{18}$ Cf. Concilium Ancyranum (314) can. 4, SCL 1, 63.

${ }^{19}$ Didache II 2, in: Constitutiones Apostolorum VII 3, 1-2, SCL 2, ed. A. Baron - H. Pietras, ŹMT 42, Kraków 2007, 177. See A. Baron, Magia i czary w “Konstytucjach apostolskich", in: Zabobony, czary i magia w Kościele starożytnym, ed. M. Ożóg - N. Widok, Opole 2013, 75-95.

${ }^{20}$ Canones Basilii 65, SCL 3, ed. A. Baron - H. Pietras, ŹMT 49, Kraków 2009, 55.

${ }^{21}$ In regards to the term $\varphi \alpha \rho \mu \alpha \kappa \varepsilon i ́$ $\alpha$ see J.-P. Audet, La Didachè. Instructions des Apôtres, Paris 1958, 287; Ph. Caspar, L'embryon au II'me siècle, Paris 2002, 29-31; Baron, Magia i czary w "Konstytucjach apostolskich", p. 87-94.

${ }^{22}$ Cf. Concilium Trullianum (691) can. 2. See The Council in Trullo revisited, ed. G. Nedungatt - M. Featherstone, Roma 1995, 67. 
"Concerning penalties for those who give or take drugs to cause abortion. Those women who give drugs which cause abortion, as well as those who take poisons to kill a foetus, shall be subject to the penalty for a murderer"23.

What is rendered here as poison is the term $\varphi \alpha ́ \rho \mu \alpha \kappa \alpha$. The penalty the same as for a homicide were, as a result, held in force in the East from the $4^{\text {th }}$ until the end of the $7^{\text {th }}$ century, and in fact, since they became incorporated in the legislation of the Church, for much longer.

In the West, on the other hand, the situation was different. Already as early as the first half of the $6^{\text {th }}$ century the Finnian penitential book from Ireland would testify to a definitely more moderate approach to abortions caused by witchcraft than it was the case in the East. According to one of the canons in this book:

"If a woman by her magic destroys the child [of another woman], she shall do penance for half a year with an allowance of bread and water, and abstain for two years from wine and meat and fast for the six forty-day periods with bread and water" 24 .

Drawing a distinction between those offences, which had previously appeared to be treated together as one, can be also found in other penitential books. For instance, the Poenitentiale Sancti Columbani (ca. 543-615) prescribes the following procedure:

"If anyone has destroyed someone by his magic art, let him do penance three years on an allowance of bread and water, and for three other years [let him abstain from wine and meat. Only in the seventh year] let him be restored to communion. But if anyone has used magic to excite love, and has destroyed no one, let him do penance on bread and water for a whole year, if a cleric, for half a year, if a layman, if a deacon for two, if a priest for three; especially if anyone has thus produced abortion, on that account let each add on six extra forty-day periods, lest he be guilty of murder"25.

${ }^{23}$ Concilium Trullianum (691) can. 91. See The Council in Trullo revisited, p. 171.

${ }^{24}$ Poenitentiale Vinniani (Finnian) (ante 550) XX, SCL 5, ed. A. Baron - H. Pietras, ŹMT 58, Kraków 2011, 16-17: "Si aliqua mulier maleficio suo partum alicuius femine desciperit, dimidium annum peniteat cum pane et aqua per mensuram et II annos abstineat se a vino et a carnibus et VI quadragesimas ieiunet cum pane et aqua", English translation taken from The Irish Penitenials, transl. L. Bieler (with emendations M. Fijak), Scriptores Latini Hiberniae 5, Dublin 1963, 79, 81.

${ }^{25}$ Poenitentiale Sancti Columbani (ca. 543-615) VI (XVIII), SCL 5, 33-34: "Si quis maleficio suo aliquem perdiderit, tribus annis poeniteat cum pane et aqua per mensuram, et tribus aliis annis abstineat se a vino et carnibus, et tunc demum in septimo anno recipiatur in communionem. Si autem pro amore quis maleficus sit et neminem perdiderit, annum integrum. cum pane et aqua clericus ille poeniteat, laicus dimidium, diaconus duos, sacerdos tres; maxime si per hoc mulieris partum quisque deceperit, ideo sex quadragesimas unusquisque insuper augeat, ne homicidii reus sit"; transl. Bieler (with emendations M. Fijak), 101. 
Yet another variation of such a practice can be found in one more Irish source, Penitential Book of Pseudo-Kummean from the $8^{\text {th }}$ century. For killing an adult person through the use of witchcraft, it prescribes seven years of penance, including three years on bread and water, whereas for the preparing of love potions laymen should perform penance for half a year, but clergymen for up to five years. Three more years on bread and water would be added if the said practice resulted in a miscarriage ${ }^{26}$. It is evident then that the periods of penance would tend to become longer over the course of time, but there were clearly some attempts made to approach the problem of responsibility in a more nuanced manner. Forms of those penitential acts also had to be expressed in more detail. To show how they were supposed to be like in practice, let us refer to the source known as Capitula Theodori (archbishop of Canterbury in the years 668-690). The following excerpt would demonstrate that the sanctions could be indeed quite rigorous at certain points, but not deadly at all:

"The penance of those who are to fast on bread and water for one year should be in each week as follows. For three days, from Thursday to Saturday, they should abstain from drinking wine, mead, honey, and ale, and from eating meat, fat, cheese, eggs, and all fatty fish. Small fish can be eaten, if available. Should there be no such fish, only one species [of fish] can be consumed, along with vegetables, legumes, fruit, if one should choose so, as well as ale. On Sundays, four days of Christmastime, Epiphany, eight days over the Eastertime, Ascension Day, four days at the feast of Pentecost, as well as on the feast days of John the Baptist, Saint Mary, Twelve Holy Apostles, Saint Michael, Saint Remigius, All Saints' Day, Saint Martin, and on the feast day of the saint venerated in the local diocese. In the aforementioned days, it is allowed to celebrate together with other Christians, which means they may consume the same food and drink, but always refraining from any drunkenness and gluttony"27.

A noteworthy distinction can be found in the so-called Excarpsum Egberti (bishop of York in the years 732-766). The extent of the penance for a homicide caused by witchcraft is dependent upon the social status of a perpetrator:

\footnotetext{
${ }^{26}$ Cf. Poenitentiale Pseudo-Cummaeani (saec. VIII) VII 1-2, SCL 5, 102.

${ }^{27}$ Capitula Theodori I 1-2, SCL 5, 161: "1. Poenitentia illius anni unius, qui in pane et aqua ieiunandus est, talisesse debet in unaquaque hebdomada. 2. Tres dies, id est feriam quintam et sabbatum, a vino, medone, mellita et cervisia, a carne et sagimine, a caseo et ovis, et ab omni pingui pisce se abstineat. Manducet autem minutos pisciculos, si habere potest. Si habere non potest, tantum unius generis piscem, et legumina, et olera, et poma, si vult, comedat, et cervisiam bibat; et in diebus Dominicis, et in Natali Domini illos quatuor dies; et in Epiphania unum diem; et in pascha, usque ad octavum diem; et in Ascensione Domini, et Pentecostes, quatuor dies; et in festo sancti Ioannis Baptistae, et sanctae Mariae, et sanctorum duodecim Apostolorum, et sancti Michaelis, et sancti Remigii, et Omnium Sanctorum, et sancti Martini, et in illius sancti festivitate, qui in illo episcopatu celebris habetur. In his supradictis diebus faciat charitatem cum caeteris Christianis, id est, utatur eodem cibo et potu quo illi, sed tamen ebrietatem et ventris ingluviem semper in omnibus caveat".
} 
"If a woman kills someone with the aid of a maleficium, specifically by a magic potion or some artifice, she must do penance for seven years; if she is poor, for four years; if a woman kills her [born] child, she must do penance for ten years" ${ }^{\prime 28}$.

Unfortunately, this provision cannot be interpreted unequivocally. The expression aliquos in the first sentence would appear to preclude miscarriages caused by the use of magic, referring rather to any person killed in this particular way. Likewise, the context is not clear enough to indicate if the said poor woman caused a miscarriage deliberately because she would have no means of subsistence for her child. If it was interpreted as continuation of the previous statement, it would be rather odd that a poor woman should be treated with more lenience in the case of a crime of murder. Most likely, however, it would refer to a miscarriage, as the expression in the following sentence, where reference is made to the killing of a child per homicidium, seems to draw a distinction between causing a miscarriage by means of some magic practice and the killing of a child after birth. The practice of prescribing a seven-year penance for a homicide caused by magic would thus begin to be introduced in the church precepts, in reference to adults as well as to the unborn children ${ }^{29}$. More frequently, however, there would be a distinction made between the two, and an abortion caused by means of a magic potion was punished with an extra penance of five forty-day periods ${ }^{30}$ or three years ${ }^{31}$.

At the beginning of the present article, I made reference to the synod of Elvira and cited one of its canons that put a perpetual excommunication on a person guilty of killing with the use of witchcraft: in this case, culprits could not be restored to communion even on their deathbed. Seven centuries later, the same canon would be incorporated in the Penitential Book of Silos (ca. 1060-1065):

"if anyone killed another person by witchcraft, he must not receive communion even on his deathbed"32.

Apparently, seven centuries of evangelizing would have produced no effect in regard to practising magic and it was decided to return to the original rigorous approach to the problem. In the course of time, Christianity would become more and more, not less and less, "magical".

${ }^{28}$ Excarpsum Egberti VII 7-9, SCL 5, 187: "Mulier si aliquos interimit arte maleficia sua, id est per poculum aut per artem aliquam, VII annos poeniteat. Si paupercula, IV annos. Mulier si occiderit filium suum per homicidium, $\mathrm{X}$ annos poeniteat".

${ }^{29}$ Cf. Poenitentiale Egberti IV 16. 21, SCL 5, 234.

${ }^{30} \mathrm{Cf}$. Poenitentiale Burgundense (ca. 700-725) 9, SCL 5, 262; Poenitentiale Merseburgense (VIII s.) V 10, SCL 5, 290.

${ }^{31}$ Cf. Poenitentiale Floriacense (ca. 775-800) 10, SCL 5, 279.

32 Poenitentiale Silense (ca. 1060-1065) 96, SCL 5, 462: "si quis maleficio interficiat alterum, nec in finem accipiat communionem". 
As it seems, the pinnacle of such attitudes was the magical practice of using holy mass with the purpose of bringing harm on a person. In the acts of the XVII synod of Toledo (694), there is a canon referring to saying mass for the living with the use of the funeral mass formula, not for a deceased person (cf. citation by Paweł Wygralak ${ }^{33}$ ), simply to bring about the situation where "a person for whom the mass is said shall fall, on account of its effectiveness, into the danger of death and eternal damnation" 34 . The bishops responded to this practice with the threat of excommunication and exile for an indefinite period of time, with the possibility of a return to the communion of the Church only in the extremity of death ${ }^{35}$.

In "The Golden Bough", James George Frazer cites the example of some Gasconian peasants who persisted in their belief in the deadly power of St. Secarius' mass celebrated in the ruins of an old church, among bats and toads. To say the mass, a particularly wicked priest had to be procured. At 11 o'clock in the night, he would begin to celebrate the "mass" by reciting all the liturgical prayers backwards. His mistress was supposed to serve at mass, the host had to be black, water from a well into which the body of an unbaptized child had been thrown would be used for wine. The person for whom such mass was offered would die a slow death for some unexplained causes ${ }^{36}$. There is much to suggest that it was a legacy of those previously mentioned sinister practices.

There has been a continued debate on whether we could speak of the phenomenon of Christian magic or only of the relics of pagan magic practised by Christians. It seems that the ceremonies such as the "unholy mass" described above, could be an argument in favour of the strictly Christianity-based magic, as no pagan would have come up with anything like that.

Translated by Marcin Fijak

\footnotetext{
${ }^{33}$ Cf. P. Wygralak, Stanowisko Kościoła wobec idolatrii i magii na terenach Galii i Hiszpanii w późnej starożytności chrześcijańskiej (VI-VII w.), Poznań 2011, 115.

${ }^{34}$ Concilium Toletanum XVII (694) can. 5, PL 84, 557: "Nam missam pro requie defunctorum promulgatam fallaci voto pro vivis student celebrare hominibus, non ob aliud, nisi ut is pro quo idipsum offertur sacrificium ipsius sacrosancti libaminis interventu mortis ac perditionis incurrat periculum".

${ }^{35}$ Cf. S. McKenna, Paganism and Pagan Survivals in Spain up to the Fall of the Visigothic Kingdom, Washington 1938, 134, n. 106.

${ }^{36}$ J.G. Frazer, The Golden Bough, vol. 1: The Magic Art and the Evolution of Kings, New York $1935,232-233$.
} 


\title{
PRAKTYKI MAGICZNE PRZECIWKO ZDROWIU I ŻYCIU CZŁOWIEKA W PÓŹNYM ANTYKU NA PRZYKŁADZIE PRAWODAWSTWA KOŚCIELNEGO
}

\begin{abstract}
(Streszczenie)
Zachowania magiczne były od niepamiętnych czasów elementem kultury. Świadectwa w postaci amuletów, różnych narzędzi czy zaklęć systematycznie są odkrywane. Magia przenikając w świat religii, stawała się jej elementem, z czasem aż do tego stopnia, że w zależności od okresu historycznego, nie sposób odróżnić jednej od drugiej. W niniejszym artykule zostały poddanie analizie, z perspektywy ustawodawstwa kościelnego, praktyki magiczne szkodzące zdrowiu i życiu. Oczywiście przepisy prawne mają na celu eliminację błędów i zagrożeń przez co przedstawiają obraz jednostronny nie oddający wszystkich aspektów życia. Niewątpliwie jednak odnoszą się do zagrożeń realnych i przez to poszerzają wiedzę o epoce. W przedstawionym tekście wzięto pod uwagę takie praktyki magiczne, które celowo i umyślnie miały szkodzić konkretnym osobom.
\end{abstract}

Key words: magic practices, synods, councils, penitential books, church legislation, late antiquity.

Słowa kluczowe: praktyki magiczne, synody, sobory, księgi pokutne, prawodawstwo kościelne, późny antyk. 